International Journal of Health Sciences
Available online at www.sciencescholar.us
Vol. 6 No. 1, April 2022, pages: 388-397
e-ISSN: 2550-696X, p-ISSN: 2550-6978
https://doi.org/10.53730/ijhs.v6n1.4559

\title{
Method of Developing Professional Competencies Future Teacher for Labor Training
}

\author{
(1) CrossMark

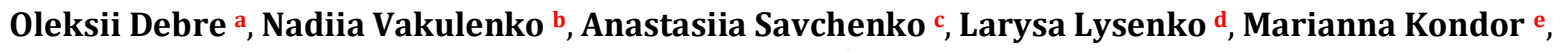 \\ Alla Kis ${ }^{f}$
}

Manuscript submitted: 29 September 2021, Manuscript revised: 9 December 2021, Accepted for publication: 25 January 2022

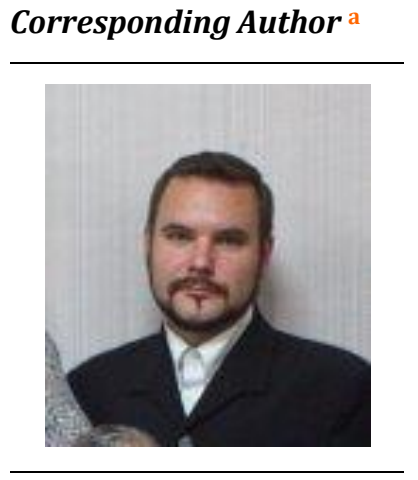

Keywords

education method; education standard; key competency; labor education; learning system; occupational education; technology learning;

\begin{abstract}
The main goal of the research was to specify the features for the key competencies' formation of teachers of labor education and technology and provide recommendations for their implementation based on the competence approach. The main method was a sociological survey among students majoring in "Labor Education and Technology". As a result of research, the essential features which arise in the preparation of students of a specialty "Labor training and technologies" of the researched university are revealed. The differences between the competencies defined in the standard for the preparation of students majoring in "Labor Education and Technology" and the professional competencies of teachers are identified. As a result was shown that the success of the progress of forming qualified competencies is ensured by creating the following conditions: introduction of a systematic approach, implementation of a contextual approach through updating the possibilities of subjects for future qualified competence. Future teachers, according to their specialties and qualifications, stimulate the conducts and methods of their development. The practical significance of the study is to form recommendations and principles for the subject competence of students majoring in "Labor Education and Technology" taking into account their future professional needs.
\end{abstract}

International Journal of Health Sciences (C) 2022.

This is an open access article under the CC BY-NC-ND license (https://creativecommons.org/licenses/by-nc-nd/4.0/).

a Poltava V. G. Korolenko National Pedagogical University, Poltava, Ukraine

b Poltava V. G. Korolenko National Pedagogical University, Poltava, Ukraine

c Poltava V. G. Korolenko National Pedagogical University, Poltava, Ukraine

d Poltava V. G. Korolenko National Pedagogical University, Poltava, Ukraine

e Poltava V. G. Korolenko National Pedagogical University, Poltava, Ukraine

f Poltava V. G. Korolenko National Pedagogical University, Poltava, Ukraine 


\begin{tabular}{|c|c|c|}
\hline \multicolumn{3}{|c|}{ Contents } \\
\hline \multicolumn{3}{|c|}{ Abstract } \\
\hline & \multicolumn{2}{|l|}{ stract } \\
\hline & \multicolumn{2}{|l|}{ 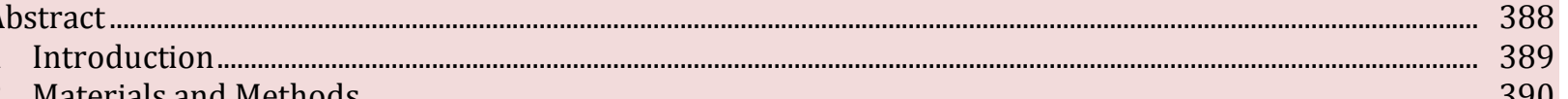 } \\
\hline & $\begin{array}{l}\text { Materials and Methods } \\
\text { Results and Discussions }\end{array}$ & 391 \\
\hline & \multirow{3}{*}{ 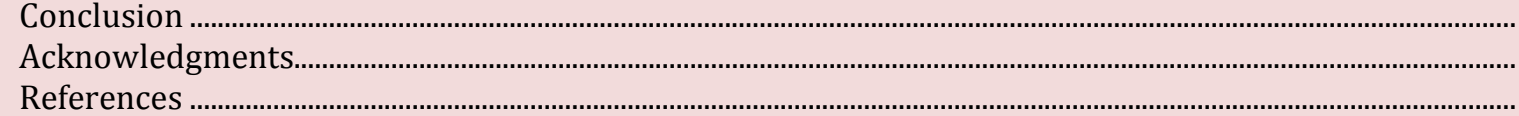 } & 393 \\
\hline & & 394 \\
\hline & & 395 \\
\hline & \multicolumn{2}{|l|}{ 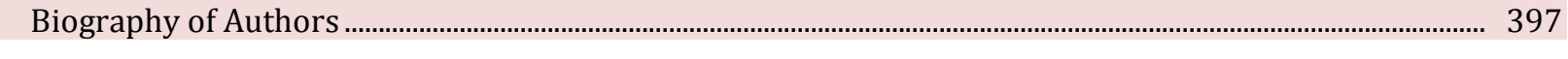 } \\
\hline
\end{tabular}

\section{Introduction}

Modern ideas about the professional training of a teacher as a specialist are related to his/her competence and ability to transfer practical knowledge to his/her successors. The question of what knowledge and skills will be useful for graduates of teacher training institutions (HEIs) (and their employers) in the near or distant future in the practical development of new types of professional activity is of paramount importance. It is this knowledge and skills that will play a decisive role in improving the professional competence of young professionals, readiness to follow the norms accepted in pedagogical society, development of social mobility and activity of professionally literate, competent specialists, development of quality of life of not only an individual but also society as a whole. This refers to a systemic vision of the development of all subject areas, including technology (Lepistö \& Lindfors, 2015; Khidoyatova et al., 2022).

The key competencies of students while studying in higher education institutions should be based on current regulations that define general approaches to the learning and training process. For HEIs, the standards of higher education of Ukraine for a certain specialty are taken as a basis, which contains a detailed description of competencies and program results of studying following the needs of the practice and the labor market.

Ukrainian Education Standards provide for the following competencies: fluency in the official language and the skill to communicate in native (if it is diverse from the official) and foreign languages, mathematical skills, competence in natural sciences, engineering, innovation, environmental competence, information, and communication competence, learning lifelong learning, civil and social competence, cultural competence, entrepreneurial and financial literacy, etc. Students who will work in secondary schools as teachers of labor education and technology must not only have professional competencies, but also soft competencies that together will promote professional and personal development on the education methods and procedures.

Bazurin (2018), proposed the issues and content of interdisciplinary responsibilities for "Labor training and technology (LTT)" specialty students. Tsisaruk (2020), describes the professional development features of the structural-functional model for labor education and technology future teachers. The proposed model is founded mainly on the social direction and included the predictable results of the continuous professional growth of the labor education and technology teacher through lifelong learning (Yüce et al., 2011; Schaper \& Pervan, 2007).

Tsisaruk (2020), analyzed the results of the experiment of the professional growth of the labor education and technology future teachers during their independent work. The author's results demonstrate the dynamics of professional development and the positive impact of lifelong learning. The issues of organizing project activities of labor education future teachers based on cloud technologies are described by Tsvilyk et al. (2018).

Kulyk et al. (2021), proposed a system of future labor education and technology teachers' professional training with the help of modern digital technologies and showed that the absence or insufficiency of digital technology for future teachers 'training decreases the level of professional development and reduces teachers' digital skills. Kulinka (2018), analyzes the possibilities of productive technologies in the design education of the labor education and technology future teachers and describes the specificity of design activities of such teachers in a productive learning environment, indicating the influence of qualified learning on the development of students' design culture and justifying the methodological aspects of training.

Debre, O., Vakulenko, N., Savchenko, A., Lysenko, L., Kondor, M., \& Kis, A. (2022). Method of developing professional competencies future teacher for labor training. International Journal of Health Sciences, 6(1), 388-397. 
Oleksiuk (2020), studies the design culture meaning approaches as a significant factor of future labor and technology teachers` education, providing the ability to perform several graphics, practical, research, and project work, and also allow to perform and combine proficiency in graphics design and technology learning systems and promote the growth of design and technical thinking (Lin \& Wang, 2012; Tseng et al., 2008; Shee \& Wang, 2008). The project method in learning as one of the most promising innovative educational technologies is, according to Khyshchenko (2019), which creates conditions for creative self-development and self-realization of future teachers during their education in HEIs. As mentioned by the author, the core of design learning and game-designed learning students activity which provides a mixture of sensual, verbal, physical, informational analogs, provides for the introduction of the basics of design (Savinova et al., 2021).

In their scientific works, Chystiakova (2020), Aleksandrova (2013), Lopuschnyak et al. (2020), comprehend a place, role, and competence method potentials in the creation of an environmental culture of the labor education and technology future teachers. The author motivates the extreme necessity to introduce new methods in the specialists' professional education, based on the content of the program educational documents, in which among the main competencies of education applicants is defined environmental, which includes a consciousness of the ecological basics of nature management, the necessity to protect nature, compliance with the guidelines of conduct in nature, efficient usage of natural resources, considerate the background and connection of economic activities and environmental preservation to safeguard sustainable development of society (Kokko, 2021; Novoa, 2021).

The essence of the competence in the economics of the labor education and technology future teachers, according to Kurok \& Kondratenko (2019), actualized by the need of society for competent teachers, accomplished of actual teaching activities in modern socio-economic circumstances. The formation of the necessary level of competencies in students is in full interdependence on the skill of the teacher, in specific, on the modeling of their competence in economics.

Stressing the importance of crafts from various pedagogical perspectives, Benić (2018), confirms the positive impact of handicrafts on learning (Sehnem et al., 2020; Koçak et al., 2013). Garber et al. (2018), addressing the issue and crafting by the community and school practices, present a collage of issues and practices, linking object creation, participatory culture, and socio-cultural transformation. Khyshchenko (2019), considers the following types of projects: research, information, and practice-oriented. So, despite such a significant number of scientific works related to the system of the subject learning field "Technology", still little studied remains the issue of preparing labor education and technology future teachers to form students' key competencies (Rieckmann, 2012; Chiru et al., 2012; Srisakda et al., 2016). The study aims to outline the training system for labor education and technology future teachers.

\section{Materials and Methods}

To regulate the system future teachers for the development of students' main competencies and to provide thematic recommendations for the implementation of practical elements, the authors conducted a sociological review between students of specialty "Labor Education and Technology" at Korolenko National Pedagogical University (Poltava, Ukraine). The survey was conducted among 700 students (500 bachelors and 200 masters) through active responses during class sessions on relevant topics. Data collection continued for eight months, data processing - two months. The answers to the questions of the questionnaire were taken into account in the semester results and added as bonus points to the evaluation system, which qualitatively affected the final result. Contents of the survey questions:

- Select from more to fewer components to form students' key competencies among such proposed: clarification of the category of the competence approach, correction of the idea of the consequence of the competence approach application, prediction of the presence of dynamic competencies in the specialist, formation, and development of the creative activity;

- Make the correlation of learning elements for lifelong professional development through independent work of two blocks. I block: consideration of the theoretical and methodological block of social order; procedural and semantic block; interactive development program and therapeutic and effective block. 
II block: purpose, conceptual principles, methodological approaches; structural components, strategies, forms, methods, means; criteria, indicators, levels;

- Make the ratio of students' main competencies according to Ukrainian Education Standards.

\section{Results and Discussions}

The results of the answers to the first question: the first place is a clarification of the competence approach category (45\%), the second place is a correction of the idea of the competence approach result (35\%), the third and fourth places are the predictions of the presence of dynamic competencies, formation and development of creative activity (10\% each). The results are presented in Figure 1.

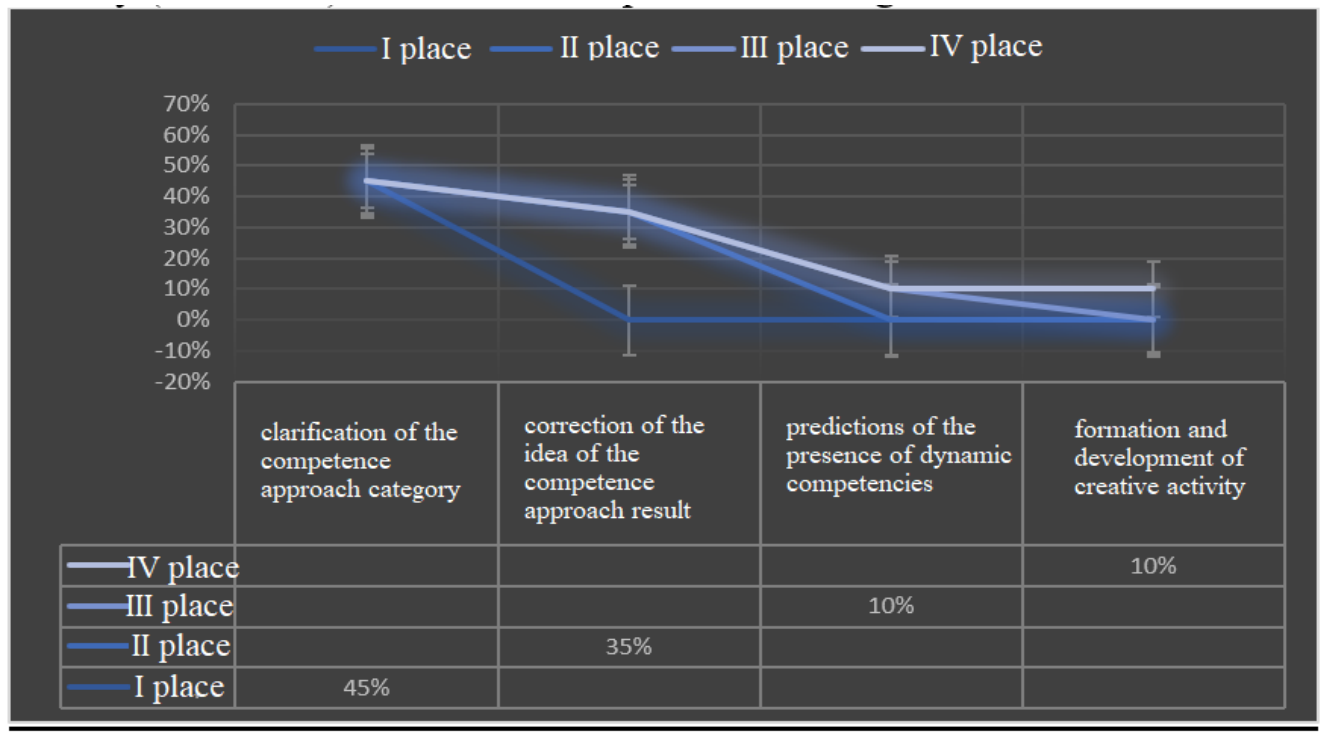

Figure 1. Components of future labor education and technology teachers' preparation to form students' key competences

The result of the student's answers to the second question by the pairwise view is presented in Figure 2 .

Debre, O., Vakulenko, N., Savchenko, A., Lysenko, L., Kondor, M., \& Kis, A. (2022). Method of developing professional competencies future teacher for labor training. International Journal of Health Sciences, 6(1), 388-397. https://doi.org/10.53730/ijhs.v6n1.4559 


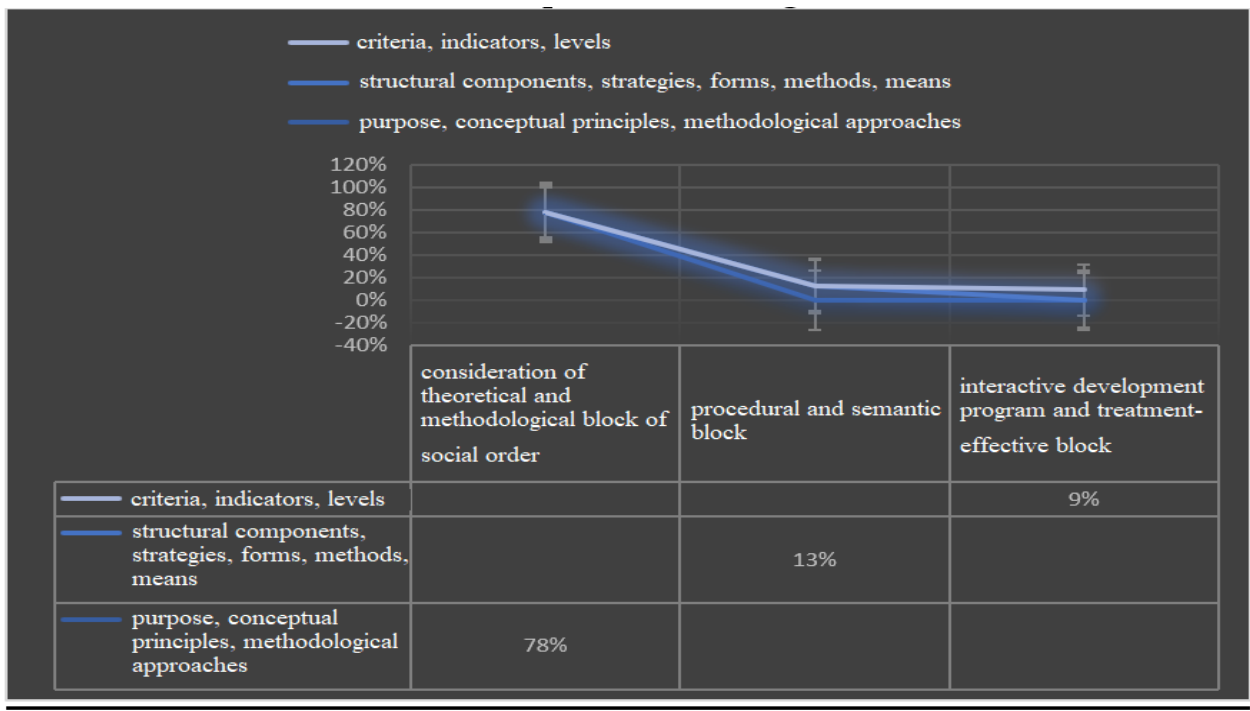

Figure 2. The ratio of elements focused on the teachers' of labor education and technology learning The result of answers to the third question about relationship between the students competencies according to Ukrainian Education Standards with the teachers' professional competencies are shown in Figure 3.

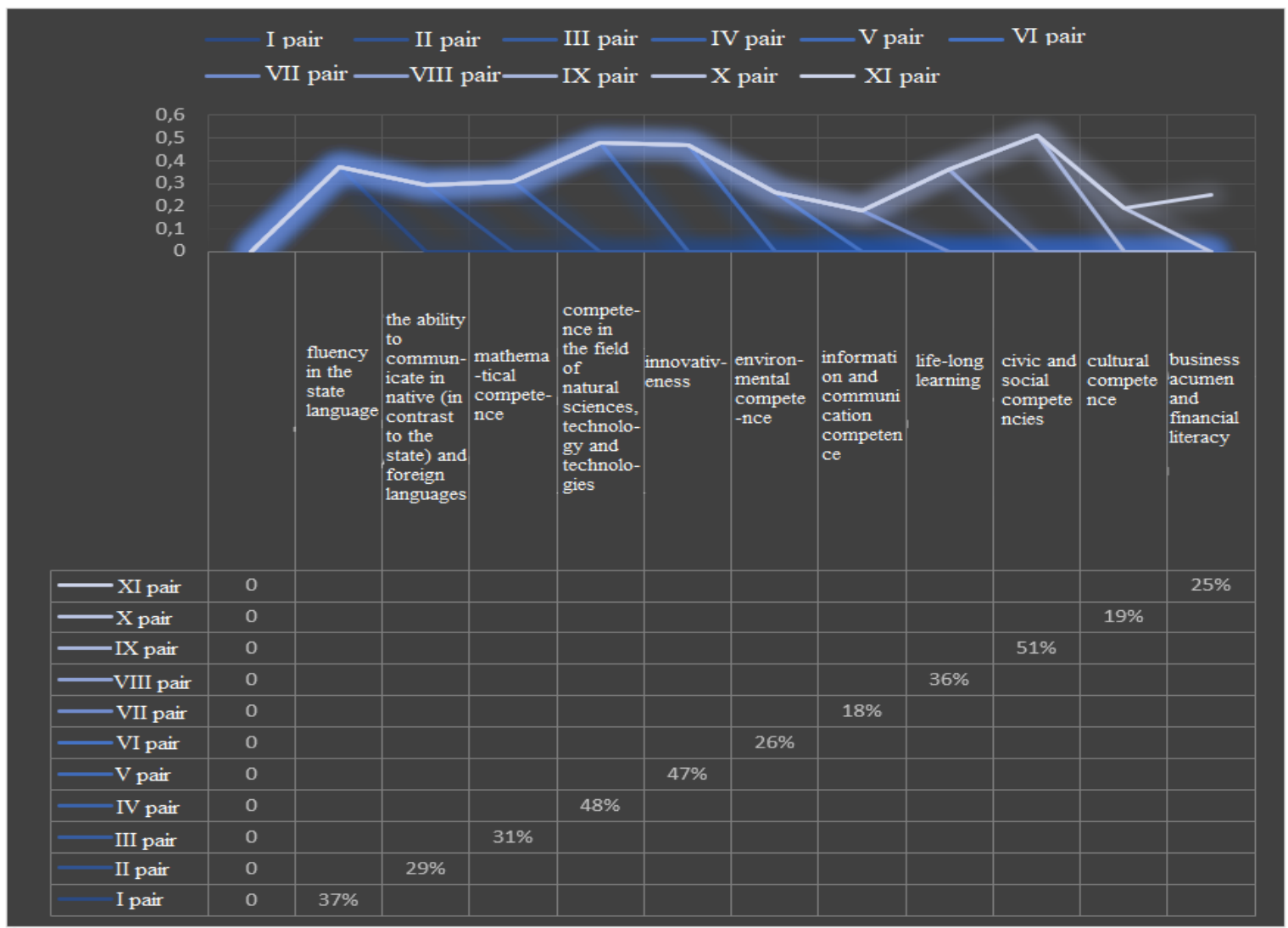

Figure 3. Relationship of the student competencies according to the Ukrainian Education Standards with the professional competencies of the labor education and technology future teachers

Thus, the obtained results outlined the grounds for scientific discussion and recommendations for the development of thematic principles. 
Discussions

Valuable in the content aspect for our study are highlighted the provisions of world science on the growth of the subject area of crafts education (labor education and technology). Pöllänen \& Urdzina-Deruma (2017), define craft education from such viewpoints: the existing craft education, the future problems, and the description of educational models which can improve labor education and technology. Kokko (2018), explored different approaches to craft education in higher education institutions and found differences related to the broader learning goals and career prospects of students.

The UNESCO resolution for the protection of cultural heritage was approved in some European countries. On such a basis, Kokko \& Räisänen (2019), present the importance of craft education for support and development of fabric craft traditions in terms of the craft teachers' education. Some authors describe the situation of craft education and training in Finland and determine that directly or indirectly on the progress of the craft education system the criteria of general basic education (Porko-Hudd et al., 2018; Widana et al., 2021). The consequences of the education system curriculum of future teachers are the problem to restructure the education and teachers' further education in general. For example, Finnish higher education institutions are experiencing continual reform due to the stressed financial condition. This gave rise to new approaches for collaborations between the four higher education institutions in Finland that offer slide knowledge education, craft, design, and skill education and craft studies. Ronkko et al. (2016), continuing their analysis of the Finnish craft curriculum emphasize the creativity of the student's skills, the achievement of various project tasks, and the application of projects. Educators focused on the technical aspect of learning view the opportunity for their students to participate in design projects as unnecessary or too challenging and distracting. Kokko (2018), Kokko et al. (2020), working on a study of craft science in Finland, Sweden, and Norway, identified different aspects of craft education through a multidisciplinary method, adjusting a variety of methods from other theoretical courses. In Sweden and Norway, craft studies have been established mainly in the field of architectural and social heritage preservation with attention to old-style skills and performative essentials of intangible cultural heritage.

Niiranen \& Hilmola (2016), to introduce fairer gender equality in Russian HEEs and encourage efforts to involve more women in technology education, will offer a brief overview of gender processes that women can master while learning and implement them in technology education. o, in the world of science, there are certain provisions about the system of technological education, which can be used in a practical application for Ukrainian educators.

\section{Conclusion}

Consequently, the effectiveness of labor education and technology future teachers training is provided by creating such conditions: implementation of a systematic approach, implementation of contextual approach through the actualization of possibilities of academic subjects to form professional competence of future teachers taking into account their specialty and qualification, stimulation of self-development process of future teachers. The dynamics of students' professional competence formation are shown through the system of interconnected stages (motivational-valuable, content, activity, and analytical-corrective), following each other in a certain sequence, within the framework of formation of the professional competence components (motivational-valuable, cognitive, activity, and reflexive). The application of an integrated approach to teaching the subject of labor education and technology led us to create recommendations for the model of forming the issue of student competence. The organization of this system is grounded on the next principles:

- Focusing on the self-value of the student as an educational process' subject;

- Linking the professional orientation of the educational content with the probable future specialized activity;

- Correlation of professional education technology and regularities of person's professional formation;

- Forward-looking nature of professional education;

- Orientation of professional education towards an individual experience of a pupil.

Debre, O., Vakulenko, N., Savchenko, A., Lysenko, L., Kondor, M., \& Kis, A. (2022). Method of developing professional competencies future teacher for labor training. International Journal of Health Sciences, 6(1), 388-397.

https://doi.org/10.53730/ijhs.v6n1.4559 
An important direction of further scientific research will be an attempt to derive the methodology of activitybased learning under the above principles. The practical significance of the study is to form recommendations and principles for the subject competence of students majoring in "Labor Education and Technology" taking into account their future professional needs.

Acknowledgments

We are grateful to two anonymous reviewers for their valuable comments on the earlier version of this paper. 


\section{References}

Aleksandrova, A. (2013). On the efficiency of the formation process of the key competencies of students future teachers in technology of modular training. Socio-Humanitarian Research and Technology, 2, 10-11.

Bazurin, V. (2018). Interdisciplinary problems as one of the ways of implementation of practical-oriented approach in teaching of general physics of future teachers of labor education and technologies. Physical and mathematical education, 1(15), 103-107.

Benić, M. Ž. (2018). The Relation between Student mood and Handicrafts in the Constructivist Classroom. Journal of Elementary Education, 11(2), 109-119.

Chiru, C., Ciuchete, S. G., Lefter, G. G., \& Paduretu, E. (2012). A cross country study on university graduates key competencies. An employer's perspective. Procedia-Social and Behavioral Sciences, 46, 4258-4262. https://doi.org/10.1016/j.sbspro.2012.06.237

Chystiakova, L. (2020). Competence approach in the formation of ecological culture of future teachers of labor education and technologies. Innovate Pedagogy, 1, 165-169.

Garber, E., Hochtritt, L., \& Sharma, M. (2018). Introduction: Makers, crafters, educators: Working for cultural change. In Makers, Crafters, Educators (pp. 1-13). Routledge.

Khidoyatova, M. R., Kayumov, U. K., Inoyatova, F. K., Fozilov, K. G., Khamidullaeva, G. A., \& Esh pulatov, A. S. (2022). Clinical status of patients with coronary artery disease post COVID-19. International Journal of Health \& Medical Sciences, 5(1), 137-144.

Khishchenko, $O 0$ (2019). Pedagogical aspects of preparation of the future teacher of labor training for design and technological activity. Young Scientist, 69 (5), 164.

Koçak, S., Kayabaşi, N., \& Şanli, H. S. (2013). Municipality of Keçiören Ankara Handicrafts Education at Profession Acquirement Courses. Procedia-Social and Behavioral Sciences, 89, 692-701. https://doi.org/10.1016/j.sbspro.2013.08.917

Kokko, S. (2018). The role of higher education in sustaining culturally significant crafts in Estonia. Design Roots. Culturally Significant Designs, Products and Practices, 231-242.

Kokko, S. (2021). Approaches to craft studies at higher education. FORMakademisk.

Kokko, S., \& Räisänen, R. (2019). Craft education in sustaining and developing craft traditions: Reflections from Finnish craft teacher education. Techne serien-Forskning i slöjdpedagogik och slöjdvetenskap, 26(1), 27-43.

Kokko, S., Almevik, G., Bentz Høgseth, H., \& Seitamaa-Hakkarainen, P. (2020). Mapping the methodologies of the craft sciences in Finland, Sweden and Norway. Craft Research.

Kulinka, Y. (2018). Productive technologies in design-education of future teachers of labor education and technologies. Bulletin of Oleksandr Dovzhenko Hlukhiv National Pedagogical University, 37, 66-75.

Kulyk, Y., Kuzmenko, P., Tytarenko, O., Tsyna, A., \& Khlopov, A. (2021). Professional training of future teachers of labor education and technology by means of information and communication technologies. Laplage em Revista, 7(Extra-C), 538-547.

Kurok, VP, \& Kondratenko, TV (2019). the phenomenon of economic competence of future teachers of labor training and technology in pedagogical theory. Collection of scientific works "Pedagogical Sciences", (89), 16-21.

Lepistö, J., \& Lindfors, E. (2015). From gender-segregated subjects to multi-material craft: Craft student teachers' views on the future of the craft subject. FormAkademisk-forskningstidsskrift for design og designdidaktikk, 8(3).

Lin, W. S., \& Wang, C. H. (2012). Antecedences to continued intentions of adopting e-learning system in blended learning instruction: A contingency framework based on models of information system success $\begin{array}{llll}\text { and task-technology } \quad \text { fit. Computers } & \text { Education, 58(1), }\end{array}$ https://doi.org/10.1016/j.compedu.2011.07.008

Lopushnyak, G., Overchuk, V., Ukraynets, L., Rudakova, S., Kabachenko, D. (2020) Innovative forms of employment under the conditions of labor market transformation. International Journal of Economics and Business Administration, 8(3), 139-149.

Niiranen, S., \& Hilmola, A. (2016). Female Technology Education Teachers' Experiences of Finnish Craft Education. Design and Technology Education: an International Journal, 21(2).

Novoa, R. B. (2021). State of the art and future applications of digital health in Chile. International Journal of Health \& Medical Sciences, 4(3), 355-361.

Debre, O., Vakulenko, N., Savchenko, A., Lysenko, L., Kondor, M., \& Kis, A. (2022). Method of developing professional competencies future teacher for labor training. International Journal of Health Sciences, 6(1), 388-397. https://doi.org/10.53730/ijhs.v6n1.4559 
Oleksiuk, M. (2020). Formation of design culture of future teachers of labor training and technologies in the process of working on design projects. Scientific bulletin of KRHPA, 1, 105-110.

Pöllänen, S., \& Urdzina-Deruma, M. (2017). Future-oriented reform of craft education. In Reforming teaching and teacher education (pp. 117-144). Brill Sense.

Porko-Hudd, M., Pöllänen, S., Lindfors, E. (2018). Common and holistic crafts education in Finland. Techne serien - Forskning i slöjdpedagogik och slöjdvetenskap, 25(3), 26-38.

Rieckmann, M. (2012). Future-oriented higher education: Which key competencies should be fostered through university teaching and learning?. Futures, 44(2), 127-135. https://doi.org/10.1016/j.futures.2011.09.005

Ronkko, M. L., Mommo, S., \& Aerila, J. A. (2016). The Teachers' Views on the Significance of the Design and Craft Teaching in Finland. Design and Technology Education, 21(2), 49-58.

Savinova, N., Berehova, M., Yanchytska, K., Stelmah, N., Biliuk, O., \& Kasatkina-Kubyshkina, O. (2021). ICT role during COVID-19 pandemic in lifelong learning for disabilities. International Journal of Health Sciences, 5(3), 594-604. https://doi.org/10.53730/ijhs.v5n3.2572

Schaper, L. K., \& Pervan, G. P. (2007). ICT and OTs: A model of information and communication technology acceptance and utilisation by occupational therapists. International journal of medical informatics, 76, S212-S221. https://doi.org/10.1016/j.ijmedinf.2006.05.028

Sehnem, S., Piekas, A., Dal Magro, C. B., Fabris, J., \& Leite, A. (2020). Public policies, management strategies, and the sustainable and competitive management model in handicrafts. Journal of Cleaner Production, 266, 121695. https://doi.org/10.1016/j.jclepro.2020.121695

Shee, D. Y., \& Wang, Y. S. (2008). Multi-criteria evaluation of the web-based e-learning system: A methodology based on learner satisfaction and its applications. Computers \& Education, 50(3), 894-905. https://doi.org/10.1016/j.compedu.2006.09.005

Srisakda, B., Sujiva, S., \& Pasiphol, S. (2016). Development of Indicators of Learner's Key Competencies Based on the Basic Education Core Curriculum. Procedia-Social and Behavioral Sciences,217, 239-248. https://doi.org/10.1016/j.sbspro.2016.02.075

Tseng, J. C., Chu, H. C., Hwang, G. J., \& Tsai, C. C. (2008). Development of an adaptive learning system with two sources of personalization information. Computers \& Education, 51(2), 776-786. https://doi.org/10.1016/j.compedu.2007.08.002

Tsisaruk, I. V. (2020). Analysis of the results of experimental research of professional development of the future teacher of labor education and technologies in technologies. Journal of Education, Health and Sport, 10(3), 295-301.

Tsvilyk, S., Harkushevskyi, V., \& Shymkova, I. (2018). Organizations of project activity of future teachers of labor education and technologies of cloud services. Modern Information Technologies and Innovation Methodologies of Education in Professional Training: Methodology, Theory, Experience, Problems, 434, 408-412

Widana, I.K., Sumetri, N.W., Sutapa, I.K., Suryasa, W. (2021). Anthropometric measures for better cardiovascular and musculoskeletal health. Computer Applications in Engineering Education, 29(3), 550561. https://doi.org/10.1002/cae.22202

Yüce, B., Karahoca, A., \& Karahoca, D. (2011). The use of electronic curriculums in occupational education to evaluate and improve the cognitive capacity of candidate software engineers. Procedia Computer Science, 3, 1418-1424. https://doi.org/10.1016/j.procs.2011.01.024 


\section{Biography of Authors}

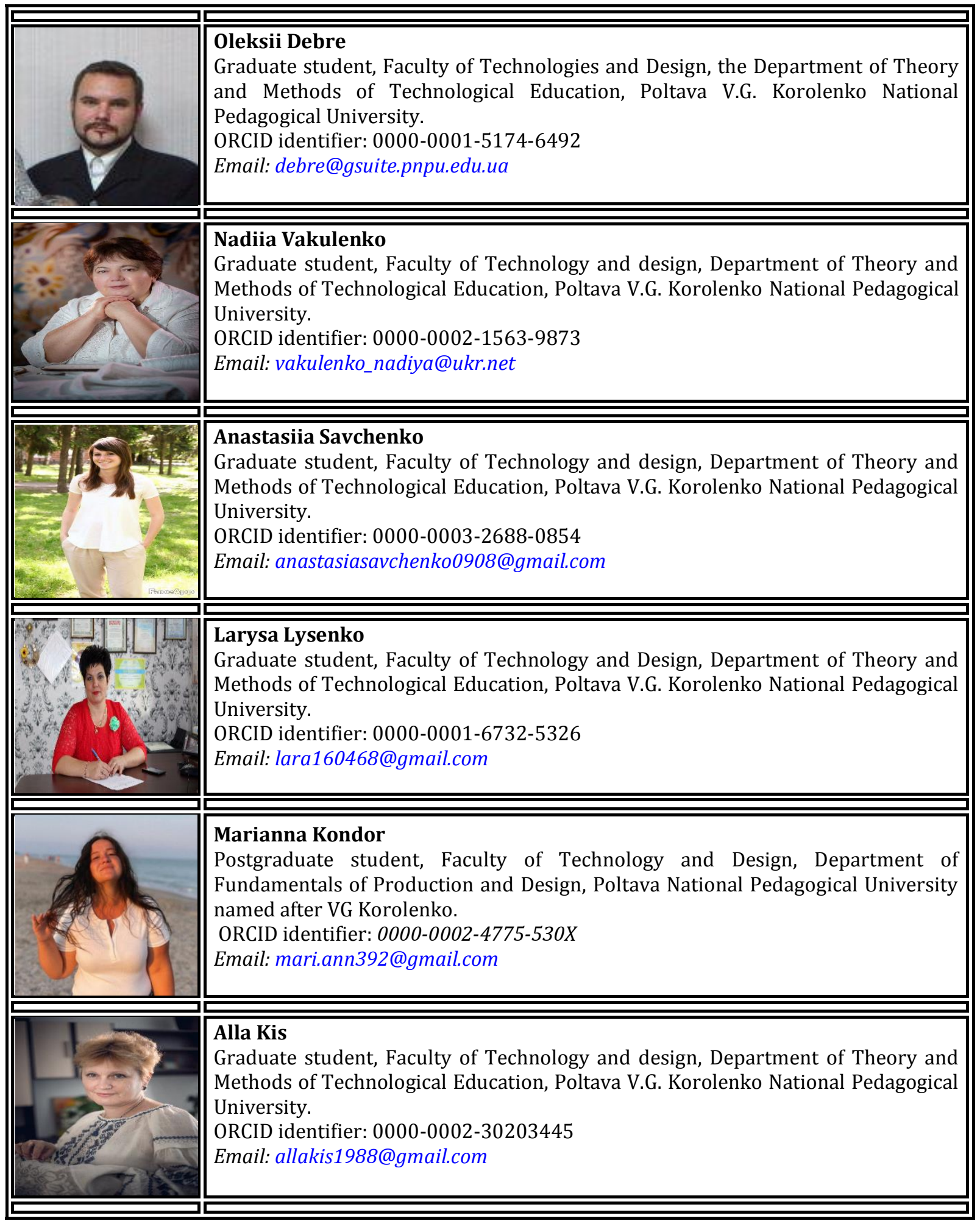

Debre, O., Vakulenko, N., Savchenko, A., Lysenko, L., Kondor, M., \& Kis, A. (2022). Method of developing professional competencies future teacher for labor training. International Journal of Health Sciences, 6(1), 388-397. https://doi.org/10.53730/ijhs.v6n1.4559 